\title{
А.X. Машарипова
}

ФИЦ Тюменский научный центр СО РАН ул. Малыгина, 86, Тюмень, 625026

E-mail: esenewka@yandex.ru

\section{ПРОБЛЕМЫ ОБУСТРОЙСТВА КОМИ ПЕРЕСЕЛЕНЦЕВ В ЯЛУТОРОВСКОМ УЕЗДЕ ТОБОЛЬСКОЙ ГУБЕРНИИ И ИХ ВЗАИМООТНОШЕНИЯ С МЕСТНЫМ НАСЕЛЕНИЕМ}

На материалах делопроизводственного характера рассматриваются основные проблемы и трудности, возникшие у вологодских переселенцев в XIX в. при переезде и обустройстве на территории Ялуторовского уезда Тобольской губернии. Анализ выявленных проблем показывает, что переселенцы были вынуждены не только налаживать быт и привыкать к условиям новой среды, но и устанавливать и регулировать отношения с местным населением и вышестоящим начальством в процессе решения вопросов на социальном, хозяйственном (бытовом) и этнокультурном уровнях.

Ключевые слова: коми (зыряне), переселение, переселенцы, инородцы, татары, Ялуторовский уезд Тобольской губернии.

Вопросы массовых переселений коми на территории Тобольской губернии в контексте освоения и заселения Сибири не раз затрагивались в работах историков, выделявших несколько этапов в процессе переселений. Первые упоминания относятся к XVI-XVII вв. и связаны прежде всего с промышленным освоением края. Зыряне считались знатоками Сибири и часто привлекались в качестве проводников в походах, шли на промыслы, в том числе с торговыми целями [Жеребцов, 2005, с. 247; 1997, с. 77-78; Филатова, 1994, с. 93; Худякова, 2005; Головнев, 1987 , c. 37]. Следующий этап охватывает период с XVIII по XIX в. и соответствует политике государства, направленной на переселение малоземельных крестьян на юг Западной Сибири вплоть до Алтая, где коми выступали в амплуа земледельцев [Головнев, 1987, с. 37; История коми..., 2004, с. 302; Лискевич, Машарипова, 2012]. В работах, посвященных изучению проблем переселенцев, рассмотрены не только процессы социальной адаптации [Адаев, 2019; Бережнова, 2009; Повод, 2009], но и социально-бытовые конфрликты [Кириллов и др., 2017; Хоменко, 2018]. Целью нашего исследования является анализ основных проблем, с которыми столкнулись коми переселенцы в условиях водворения и обустройства, их взаимоотношений с местным населением и причин возникновения конфликтных ситуаций.

В работе над статьей были использованы архивные документы, сосредоточенные в фондах Государственного исторического архива г. Тобольска (ГУТО ГАТ) (ф. 152, 154, 156, 335). Материалы делопроизводственной документации содержат различные жалобы, прошения крестьян переселенцев, старожилов и коренного населения, касающиеся разрешения земельных споров, возникших при отводе земельных участков, а также судебные разбирательства, отражающие столкновение интересов различных сторон. Документы по межевым работам (отвод и определение границ), принадлежности того или иного участка, землеустроительные споры между жителями соседних деревень Ялуторовского уезда содержатся в фонде поземельно-устроительной партии (ф. 48) в Государственном архиве Тюменской области (ГУТО ГАТО). Статистические данные о численности переселенцев с указанием на места выхода и водворения хранятся в ф. 13 Государственного архива Челябинской области (ГУ ОГАЧО). В фрондах Государственного архива Омской области (КУОО «ИсАОО) - ф. ИЗ (Главное управление Западной Сибири) и Государственного архива Вологодской области (КАУ ВО «ГАВО») - ф. И15 (Вологодское Губернское по крестьянским делам Присутствие) сохранились документы, содержащие переписку по поводу отвода земельных участков, приговоры сельских сходов, а также статистические сведения о переселенцах. Обширная группа источников дает возможность проследить и проанализировать деятельность государственных органов, а также выявить причины переселений и установить основные проблемы, связанные с обустройством на новом месте. Архивные материалы были дополнены полевыми исследованиями, которые проводились ИПОС СО РАН (сейчас ТюмНЦ СО РАН) в 2005-2008 гг. на юге Тюменской области, где в настоящее время проживают 


\section{Проблемы обустройства коми переселенцев в Ялуторовском уезде Тобольской губернии...}

потомки коми переселенцев (Заводоуковский, Юргинский, Ялуторовский и Ярковский р-ны). Основное внимание было направлено на изучение процессов формирования и развития комизырянского населения, выявление сохранности традиционной культуры и исторической памяти. В результате исследований был собран разносторонний материал по этнической истории, материальной и духовной культуре коми.

Поиск новых территорий и обустройство занимали у первых переселенцев немало времени. При выборе места для поселения коми-зыряне сначала ориентировались на свободные, никем не заселенные земли, которые по своим природно-климатическим характеристикам были максимально приближены к условиям их прежнего места проживания [Вибе, 1994, с.105; Казанник и др., 2008, с. 65; Конаков, Котов, 1991, с. 48-49]. На земли, расположенные на юге Тобольской губернии в Ялуторовском уезде (совр. Ялуторовский и Ярковский р-ны Тюменской обл.), коми начали переселяться в первой трети XIX в. из Вологодской губернии Усть-Сысольского и Яренского уездов. Первые компактные поселения появляются в 1841 г. на территории Томиловской волости - с. Ивановское, д. Александровка и позднее выс. Тихвинский. Местное руководство к переселению семейных групп коми, желавших поселиться в округе, видимо, было не готово, так как на протяжении четырех лет они оставались не причисленными и не имели возможности обзавестись своим хозяйством. По воспоминаниям жителей д. Ивановки, первым пристанищем для них стало оз. Балаганное, у которого был разбит лагерь, «жили в землянках» [Попов, 1982, с. 7; Подкопаева Н.Ф., 1931 г.р.]. Часть крестьян временно были подселены к старожильческим обществам в близлежащие деревни Заводоуковской (Плюхина) и Томиловской (Заводопетровское, Бердюгино, Коктюль, Криволуцкая, Мыс, Петелино, Томилово, Хохлово, Чукреево) волостей [ГУТО ГАТ, фр. И156, оп. 15]. В поисках заработка переселенцам нередко приходилось переселяться из одной деревни в другую. Так, например, семья Федора Семеновича Манова с момента прибытия в Томиловскую волость и до причисления к с. Ивановскому успела пожить в д. Криволуцкой [Там же, д. 1183, л. 61] и в д. Коктюль [Там же, д. 1185, л. 24].

Причиной массового ухода коми-зырян с прежних мест жительства послужила нехватка земли и тяжелые условия: «...крестьяне на родине имели на каждую наличную душу земельный надел в 30 саж., кроме того, с каждой ревизской души взимались платежи по 8 руб. 95 коп. в год» [ГУ ОГАЧО, ф. И13, оп. 1, д. 31, л. 20]; «Из-за неурожая хлеба за ними осталась за прошлые годы обширная казне недоимка» [ГБУТО ГАТ, фр. И156, оп. 11, д. 439, л. 28]; «был сильный голод, природные условия не позволяли заниматься земледелием» [Подкопаева Н.Ф., 1931 г.р.]; «жилось трудно, еле сводили концы с концами» [Кононова А.Г., 1921 г.р.]. Прибывшие в Тобольскую губернию одной партией государственные крестьяне в количестве 424 чел. обратились в Тобольскую казенную палату с просьбой о причислении к Ялуторовскому уезду, но «общество просителей по месту их прежнего проживания на увольнение последних, по причине числящихся за ними недоимок, выступило против». Решая вопрос о водворении переселенцев, которые находились в крайне бедственном положении, Министерством государственных имуществ было принято решение оставить крестьян, но с условием уплаты недоимок с рассрочкой на восемь лет [ГУТО ГАТ, фр. И156, оп. 11, д. 439, л. 369; И152, оп. 41, д. 354, л. 80]. Таким образом, числившиеся за переселенцами недоимки переводились на новое место жительства и подлежали обязательной уплате. По Указу Казенной палаты от 6 июня 1841 г. за № 3615, основанному на положении Совета Главного Управления Западной Сибири, вологодские крестьяне поступили на причисление к Юргинской волости по увольнительным приговорам и были поселены на землях инородцев юрт Чечкинских и Ново-Атьяловских [ГУТО ГАТ, ф. И152, оп. 41, д. 354 , л. 6 ; И156, оп. 11, д. 439, л. 577]. Всего в земельный надел к переселенцам на 565 душ муж. п. отошли земли по правую сторону р. Тобол в количестве свыше 10 тыс. дес. удобной земли, а вместе с неудобной 14384 дес. 2106 саж. [Там же, л. 68, 186].

Несмотря на разрешение властей, переселенцы столкнулись с рядом трудностей, которые привели к конфрликту с местным населением по поводу земли и выяснения ее законных владельцев. Спор о землях, выбранных к заселению вологодскими переселенцами, растянулся на долгие годы, что повлекло за собой многочисленные претензии со стороны татар. Так, в 1841 г. «инородцы» обратились к Господину Начальнику Тобольской губернии с жалобой на незаконные действия Тобольской казенной палаты, нарушившей их права владения на земли [ГУТО ГАТ, ф. И.335, оп. 1 , д. 400 , л. 15]. Дело было передано на рассмотрение в Совет Главного управления Западной Сибири, где состоялось определение о передаче документов на рассмотрение в Ялуторовский окружной суд. Рассмотрев обстоятельства дела в декабре 1858 г., суд принял решение в 


\section{А.Х. Машарипова}

пользу татар: «...земли, владеемые татарами юрт Чечкинских и Ново-Атьяловских, как укрепленные за ними по актам, дающим право крепостного владения, считать их собственными, а вологодским переселенцам отвести для поселения другие земли» [Там же, л. 10]. Спустя два года обстоятельства данного дела были повторно рассмотрены в Губернском суде. В результате по определению суда от 9 декабря 1860 г. земли инородцев были признаны казенными, но «только находящимися в пользовании татар», а также было принято решение «оставить за татарами только то количество земли, которое приходится им по числу душ в 15 дес. пропорции, излишнюю же землю отрезать в казну» [ГУТО ГАТ, фр. И152, оп. 41, д. 354, л. 46-47].

В последующем ходатайства от инородцев рассматривались дважды в Правительствующем Сенате. При первом рассмотрении данного вопроса было сделано распоряжение о вознаграждении татар «за потерю означенных земель», но заявители через поверенных лиц 29 января 1861 г. выступили с апелляционной жалобой, требуя отменить решение Правительствующего Сената, а спорные земли признать их собственностью [Там же, л. 12]. В феврале 1866 г. последовало новое распоряжение Правительствующего Сената, по которому Министерство государственных имуществ по соглашению с обществом тех татар должно было изыскать новые земли взамен утраченных [ГУТО ГАТ, ф. ИЗ35, оп. 1, д. 400, л. 16-17]. В качестве компенсации инородцам не раз предлагались соседние свободные казенные земли за Петровским заводом (в дачах Юргинских) [Там же, л. 79, 179], а также в округах: Тюменском - по реке Иске и реке Тавде, в Тарском - по реке Иртыш, с получением из казны положенных законом пособий и льгот на переселение [ГУТО ГАТ, ф. И335, оп. 1, д. 400, л. 189; ф. И.152, оп. 41, д. 354, л. 100]. На что татары постановили приговор, по которому наотрез отказались принять участок из смежных казенных земель, объяснив причину тем, что эти земли «отдалены от их места жительства болотами и не пригодны по качеству и ценности к сенокошению и к хлебопашеству». Жители юрт считали, что переселение вологодским крестьянам, поселившимся на этих землях около двадцати лет назад, будет не так обременительно, как татарам, обитающим на этих землях более трехсот лет со времен покорения Сибири и «потерпевшим разорение через лишение самых лучших и удобных земель» [ГУТО ГАТ, ф. ИЗ35, оп. 1, д. 400, л. 54, 80, 182]. Стремление инородцев любыми способами вернуть землю привело к тому, что в 1877 г. земли бывших переселенцев, а также земли, «владеемые» инородцами, были повторно сняты на план. Как выяснилось, на каждую ревизскую душу у инородцев приходилось по 23 дес. земли, а у крестьян переселенцев - по 17 дес., что превышало пропорцию, назначаемую законом в надел государственным крестьянам, поэтому жалоба татар была отклонена [ГУТО ГАТ, ф. И152, оп. 41, д. 354, л. 315]. В декабре 1883 г. по Указу Правительствующего Сената было принято решение о вознаграждении инородцев юрт Чечкинских и Ново-Атьяловских, которое должно было состоять в возмещении им денежной стоимости утраченных земель, на что инородцы снова отказались, требуя возврата прежних земель, уступив крестьянам лишь площадь под их поселения [ГУТО ГАТ, фр. ИЗ35, оп. 1, д. 400, л. 4]. В 1895 г. поверенный от инородцев Кильтазан Кулушев дважды обращался с ходатайством в Министерство государственных имуществ. В первом случае его просьба содержала предложение о возложении на вологодских переселенцев обязанностей по уплате всех сборов на условиях арендной платы в государственную казну, требуемых с его доверителей, а во втором ходатайстве он просил о командировании землемера для определения количества земли, отошедшей переселенцам, в целях установления размеров следуемого за нее вознаграждения. Оба эти ходатайства были отклонены с указанием обратиться по данному делу в судебном порядке в вышестоящие инстанции [Там же, л. 5]. Последний иск о присуждении инородцам денежной стоимости взамен отчужденных земель Окружным судом был отклонен 24 апреля 1915 г. [Там же, л. 201].

Потомки переселенцев до сих пор помнят рассказы о конфрликтах с татарами. Так, вблизи с. Александровского есть урочище Воинское, названное так потому, что именно там произошли первые столкновения между татарами и зырянами. Драки, как правило, происходили из-за сенокосных и рыболовных угодий [Попов, 1982, с. 7]. Чечкинские татары не давали зырянам косить траву за озером, поэтому покосы приходилось брать в аренду: «В Чечкино был богач. Зыряне арендовали у него покос за продукты. Брали берестяной туес на два литра сметаны и ходили к нему за разрешением. Пока он сметану ел, можно было косить» [Кутькин П.Т., 1928 г.р., Уляшева Ф.И., 1925 г.р.]. Инородцы оспаривали возможность для зырян сдавать землю в аренду, так как считали ее своей. Так, в 1844 г. жители д. Александровки сдали в аренду крестьянину Василию Федотовичу Гилеву 3 дес. земли на р. Юрге сроком на 50 лет. На этом 


\section{Проблемы обустройства коми переселенцев в Ялуторовском уезде Тобольской губернии...}

участке предполагалось построить мукольмольную мельницу, а при ней пильню для пилки леса на условиях уплаты ежегодного оброка на сумму 3 руб. серебром, из которого одна половина должна была поступить в казну, а другая в пользу общества [ГУТО ГАТ, ф. И152, оп. 41, д. 219, л. 1-3]. Но строительство мельницы было приостановлено по жалобе татар д. Чечкино, у которых своя мельница находилась на полверсты ниже по р. Юрге, а новая мельница стала ее подтоплять [Там же, л. 7-12].

Спорные вопросы по поводу обустройства на новом месте были связаны не только с хозяйственной деятельностью, но и с «приходской» жизнью. После получения разрешения на водворение остро встал вопрос о строительстве храма. В сентябре 1842 г. вологодские переселенцы собрали сельский сход, на котором было принято решение обратиться в Ялуторовское духовное правление с просьбой о постройке деревянной церкви на каменном фундаменте вместо имеющейся часовни, находящейся в д. Александровке. Отдельный приход в д. Александровской должен был объединить не только жителей этих населенных пунктов, но и будущих переселенцев, поселенных между иноверцами магометанского вероисповедания [ГУТО ГАТ, ф. И152, оп. 31, д. 79, л. 31-79]. Причиной послужило довольно большое расстояние от приходской церкви, расположенной в с. Боровинское в 60 верстах. Ближайший приход имелся в Тюменском округе с. Покровского (25 верст), но зимой туда было трудно добираться, а весной изза разлития рек и болот и вовсе было невозможно проехать [ГУТО ГАТ, ф. И156, оп. 11, д. 439, л. 43]. Из-за дальности приходов священник не успевал прибыть вовремя, что препятствовало исполнению «мирских треб» [Там же, л. 24, 43, 242].

По Указу Тобольской духовной консистории от 14 октября 1844 г. за № 1502 епархиальным начальством было разрешено построить церковь, в 1846 г. были выданы план и фасад. Общество крестьян с. Ивановского выступило против строительства деревянной церкви в д. Александровской, объясняя причину своего отказа тем, что «находятся в неустроенном положении и крайней бедности», «семьи их испытывают недостаток в пропитании», а также за ними «числится недоимка казне, поэтому они своего согласия не давали, а были включены заочно» [ГУТО ГАТ, ф. И335, оп. 1. д. 400, л. 21; фр. И156, оп. 11. д. 439, л. 19, 22-27]. Но после того как ими будут уплачены в казну государственные недоимки и подати, числящиеся за ними по Вологодской губернии, они хотели бы построить церковь в своем селении [ГУТО ГАТ, фр. И156, оп. 11, д. 439, л. 34]. Это привело к конфликту двух сторон. Зыряне д. Александровской заявили, что построят церковь самостоятельно, заготовив для строительства храма сосновый строевой лес и кирпич с известью для фундамента [Там же, л. 792]. Строительный материал с течением времени начал постепенно приходить в негодность, а церковная утварь, состоявшая из икон, книг, колокола и ризницы, оставалась без употребления, поэтому многие жители по причине убытков стали отказываться от сооружения храма [Там же, л. 661]. Хотя для возведения храма препятствий не было, епархиальное начальство, сославшись на неоконченное дело в суде о землях переселенцев, в строительстве им отказало. В 1863 г. священнослужитель Иоанн Соколов обратился с рапортом в Ялуторовское духовное правление, в котором доложил, что жители д. Ивановской отказались участвовать в найме квартиры для причетника и все расходы легли на жителей д. Александровской [Там же, л. 916, 923-924]. Характеризуя зырян с. Ивановского как народ «зловредный, своенравный, ужасно грубый и вовсе непокорный», просил прислать земского начальника для разрешения этого вопроса, так как «на бумаге распоряжения и приказания они не слушают, а он со своей стороны боится им слово сказать вопреки их желанию, так как народ отчаянный и готовый на все низкие поступки» [Там же, л. 924]. На этих же крестьян жаловался священник Алексей Серебрянников: «жители с. Ивановского и выс. Тихвиновского не платят ругу священнослужителю, причт содержится только за счет крестьян д. Александровской, жителей очень бедных» [Там же, л. 321, 745]. За неимением своей церкви жители с. Ивановского посещали Николаевскую церковь с. Бердюгинского (40 верст) Томиловской волости, а жители д. Александровской - приход Покрово-Богородицкой церкви с. Покровского Тюменского уезда [ГУТО ГАТО, ф. И255, оп. 3]. Вопрос о строительстве церкви затянулся на долгие годы. В с. Ивановском церковь во имя святого Иоанна-Предтеченья была построена на средства прихожан в 1876 г., а в д. Александровке - Троицкая церковь только в 1897 г. [Справочная книга..., 1913, с. 181].

Положение переселенцев в первое время было довольно трудным, что сводилось не только к спорным вопросам по поводу земельного надела. Трудности касались и хозяйственного обустройства. Территория, на которой поселились крестьяне, была покрыта густым смешанным лесом, необходима была распашка земли, требовавшая тяжелого физического труда. Поэтому вначале земледелие оставалось вторым источником дохода. На первый план выдвигались от- 


\section{А.Х. Машарипова}

ходнические работы - заготовка смолы, дегтя и дров для речного пароходства. В переписке по гражданскому ведомству чиновники отмечали, что «качество и ценность владеемых переселенцами земель повысилось с введением на них сельского хозяйства, а не во времена, когда земли находились во владении инородиев, занимающихся по образу жизни звериною охотой и платя за землю в казну ясак» [ГУТО ГАТ, ф. И152, оп. 41, д. 354, л. 187-188]. Вологодские переселенцы более четырех лет были лишены постоянной оседлости, что не могло не сказаться на их экономическом положении [ГУТО ГАТ, ф. И156, оп. 11, д. 439, л. 173]. Вопрос об их переселении на новое место жительства даже не рассматривался, так как они «терпели изнурительные убытки» [ГУТО ГАТ, ф. И335, оп. 1, д. 400, л. 70-86]. В 1844/45 гг. крестьяне понесли потери по причине неурожая хлеба на сумму 3 тыс. руб. сереб. и упадка сельскохозяйственных животных от «заразительной болезни»: «свалилось» 205 лошадей и 202 коровы [ГУТО ГАТ, фр. И152, оп. 31, д. 79, л. об. 70]. Только у жителей д. Александровской ущерб составил до 10 тыс. руб. ассигнациями. Ежегодные наводнения с 1854-1867 г. привели к крайнему разорению крестьян, и они были не в состоянии выплачивать государственные подати и выполнять повинности, на которые просили дать им отсрочку [ГУТО ГАТ, ф. ИЗ35, оп. 1, д. 400, л. 80].

Следующая партия переселенцев прибыла в начале 1850-х гг. и поселились на свободных казенно-оброчных участках, частично на землях крестьян в Заводоуковской волости, основав в 1860 г. - д. Яковлево, в 1864 г. - д. Каменку. Всего было перечислено 157 семейств [ГУ ОГАЧО, ф. И13, оп. 1, д. 29, л. 11]. Основным мотивом переезда в Ялуторовский уезд являлось наличие родственников, которые могли на первое время приютить переселенцев. Причиной переезда послужили постоянные неурожаи и, как следствие, голод. В рапорте вышестоящему начальству уездный исправник Усть-Сысольского уезда писал, что «в его волостях нет ни одного крестьянина, который бы не имел недоимок», «народ настолько беден, что многие не имея хлеба давно уже отправились на заработки в разные местности, чтобы прокормить свои семейства» [КАУ ВО «ГАВО», ф. И15, оп. 1, д. 4833, л. 3]. К примеру, недоимки по Борисовской волости превысили годовой оклад в 4 раза, а по Кайгородской волости - более чем в 9 раз [Там же, л. 4-5]. Так, семья Матвеева Ивана Александровича из Усть-Сысольского уезда ВизинскоТроицкой волости Гривенско-Георгиевского сельского общества в количестве 8 чел. (6 чел. муж. п. и 2 чел. жен. п.) пожелала отправиться в Сибирь для приискания удобных мест. В ноябре 1857 г. сельский сход разрешил семье отправиться в Заводоуковскую волость, но, так как за семьей числились государственные подати и прочие повинности, общество выбрало из своей среды трех поручителей, распределив между ними участок земли и сенные покосы Матвеева на условиях уплаты долгов [Там же, л. 9].

Земельный надел крестьян, образовавших д. Каменку, был расположен в местности «слегка возвышенной, совершенно сухой и ровной, где не было низин и лугов, сенокос был разбросан небольшими клочками по полянам среди березовых рощиц». В засушливые годы травяной покров получался скудный, поэтому сена не хватало: «...самое большее, в средние даже по урожаю годы на дворе собиралось 30-40 копен, а в лучшие годы почти все домохозяева вынуждены были арендовать сенокос на стороне» [ГУТО ГАТО, ф. И48, оп. 1, д. 384, л. 30]. На их участке не было водных ресурсов, поэтому они были вынуждены поселиться на границе Падунской казенной лесной дачи, расположив свои усадьбы по течению р. Камешника. Препятствий в использовании смежных казенных участков крестьяне не встретили, поэтому начали производить на них распашку земли и выпускать скот. С учреждением лесничества дальнейшие распашки были запрещены; осознав стесненность своего положения, приняли решение ходатайствовать об изменении границ своего надела [Там же, л. 18-19]. В течение шести лет жители д. Каменки обращались с просьбой об увеличении угодий в Тобольскую казенную палату и в Управление государственных имуществ. Все их прошения оставались без внимания [Там же, л. 20], поэтому крестьяне продолжали самовольно пользоваться казенными землями, так как им не хватало воды, особенно в засушливое время года [Там же, л. 28]. Жители д. Яковлево столкнулись с той же проблемой, переселившимся в разное время переселенцам не хватало земли.

Последняя партия переселенцев прибыла в 1869 г. из Усть-Сысольского уезда ВизинскоТроицкой волости Воронцовского, Вотчинского, Енъ-Янбского и Межадорского обществ в количестве 86 семей. У себя на родине переселенцы ходатайствовали о выдаче им денежного пособия: на каждую семью по 20 руб. на путевые издержки и 40 руб. на первоначальное «домообзаводство», покупку скота и земледельческих орудий [КУОО «ИсАОО», ф. И3, оп. 6, д. 7884, л. 41, 44]. Переселенцы из Вологодской губернии отправились в Тобольскую губернию несколькими партиями в фев- 
Проблемы обустройства коми переселенцев в Ялуторовском уезде Тобольской губернии...

рале и марте 1869 г. и были зачислены по Тобольской губернии 30 сентября 1869 г. [Там же, л. 213]. Государственное пособие было выделено только на 80 семейств, а причислилось 94 [Там же, л. 393-396]. В 1870 г. ими было основано первое поселение - выс. Курган (6 семей), а спустя два года после причисления образованы в 1871 г. д. Бельховка (25 семей) и д. Чуманова (28 семей). Отдельные семьи поселились в близлежащих деревнях среди русского населения, в частности: д. Тапы - 22 семьи, д. Вяткина - 13 семей, д. Балаганы - 8 семей, с. Плетневское -7 семей, с. Агаракское -5 семей, по 6 семей проживало в д. Шевелевой и выс. Согры, по три семьи - в деревнях Березовка, Лабиной, Порогов и Сосновка, по одной семье - в деревнях Аниковка, Метлякова, Верхречек и Кучеметьевки [ГУ ОГАЧО, фр. И13, оп. 1, д. 10, л. 11-26].

Напряженные отношения возникли между жителями д. Чуманова и старожилами д. Березовки Выползовского сельского общества, где последние пытались нажиться за счет переселенцев. Так, в середине 1890-х гг. они заключили сделку - договорились о «полюбовном» переделе земли. Крестьяне д. Березовки обещали отвести в пользование крестьян д. Чуманова сосновый лес, взамен которого взяли пахотную землю в количестве 80 дес. Лесом переселенцы пользовались только один год, так как в последующие годы в этом им было отказано, а пахотную землю не вернули [ГУТО ГАТО, фр. И48, оп. 1 , д. 771 , л. 10]. Крестьянам д. Бельховки из-за недостатка земельных и сенокосных угодий ежегодно приходилось брать в аренду казенно-оброчную землю, так как выделенный участок изначально был рассчитан на 44 чел., а к 1912 г. количество жителей деревни достигло 159 [Там же, д. 675, л. 12-13]. Таким образом, каждая сторона была заинтересована в наличии сельскохозяйственных земель: выгонов для скотины, пашен и покосов.

При первых контактах между переселенцами и старожилами изначально сложились непростые отношения, что определялось не только языковым различием, но и столкновением хозяйственно-бытовых интересов. Погодные условия (засуха, наводнения) и бедственное положение привели к массовому и стихийному переселению коми из Ялуторовского уезда. Часть семей приняли решение на переезд в Киргизские степи, Заилийский край [Андреев, 2007, с. 164]. Так, из с. Ивановского в 1855 г. выбыло 20 семей, а из д. Александровской - 45, все они были зачислены в казачье сословие [ГУТО ГАТ, ф. И154, оп. 8, д. 932, 947]. Часть вологодских переселенцев, пожив какое-то время в Заводоуковской волости, в 1870 г. переселились в г. Кокчетав (13 семей) [ГУ ОГАЧО, ф. И13, оп. 1, д. 29, л. 20]. Семья В.В. Можегова из д. Яковлево в 1893 г. выбыла в д. Николаевскую Кайлинской волости Барнаульского округа Томской губернии [ГУТО ГАТ, ф. И154, оп. 18, д. 4а, л. 73]. В переселении участвовали в основном безземельные и малоземельные крестьяне. Решение многих социально-бытовых проблем, с которыми столкнулись переселенцы, напрямую зависело от государственной власти в лице ее местных представителей, но помощь оказалась не существенной, о чем говорят постоянные жалобы и ходатайства крестьян. Судебные разбирательства были растянуты на десятилетия. Несмотря на то что переселение крестьян и распределение земельного фонда находились под контролем административных властей, не предусматривался разбор вопросов об увеличении земельного надела при естественном приросте населения.

Список информантов:

Кононова А.Г. 1921 г.р.

Кутькин П.Т., 1928 г.р.

Подкопаева Н.Ф., 1931 г.р.

Уляшева Ф.И., 1925 г.р.

БИБЛИОГРАФИЧЕСКИЙ СПИСОК

Источники

ГУТО ГАТ. Ф. И152. Оп. 31. Д. 79; Оп. 41. Д. 219, 354. Тобольское губернское управление, г. Тобольск Тобольская губерния.

ГУТО ГАТ. Ф. И154. Оп. 8. Д. 711, 945; Оп. 16. Д. 19; Оп. 18. Д. 4а. Тобольская Казенная Палата, г. Тобольск Тобольской губернии.

ГУТО ГАТ. Ф. И156. Оп. 11. Д. 439; Оп. 15. ДД. 1183, 1185; Тобольская духовная консистория, г. Тобольск, Тобольская губерния.

ГУТО ГАТ. Ф. ИЗ35. Оп. 1. Д. 400. Отделение по крестьянским делам Тобольского губернского управления, г. Тобольск Тобольской губернии (1895-1918 гг.).

ГУТО ГАТО. Ф. И48. Оп. 1. Д. 60, 68, 1169. Курганско-Ялуторовская поземельно-устроительная партия, г. Тюмень Тобольской губернии. 


\title{
А.Х. Машарипова
}

ГУ ОГАЧО. Ф. И13. ОП. 1. Д. 29, 31. Заведующий передвижением переселенцев по Европейской России и Западной Сибири Министерства земледелия Российской империи; г. Челябинск Челябинского уезда Оренбургской губернии (1884-1917).

КУОО «ИсАОО». Ф. ИЗ. Оп. 6. Д. 7884. Главное Управление Западной Сибири.

КАУ ВО «ГАВО». Ф. И15. Оп. 1. Д. 4833. Вологодское Губернское по крестьянским делам Присутствие.

\section{Лuтература}

Адаев В.Н. Опыт описания экстремальной адаптации: Чуваши-переселенцы XX века в урманной тайге // Вестник археологии, антропологии и этнографии. 2019. № 3 (46). С. 137-148. URL: http://www.ipdn.ru/rics/va.

Андреев С.М. Источники формирования сибирского линейного казачества в дореформенный период // Известия Томского политехнического университета. 2007. Т. 310. № 3. С. 161-165.

Бережнова М.Л. Первые шаги на новой родине: Новые модели природопользования белорусских переселенцев в урмане // Изв. АлтГУ. Сер. История. Барнаул, 2009. № 4/3 (64). С. 32-36.

Вибе П.П. Переселение крестьян Европейской России в Тобольскую губернию во второй половине XIX начале XX вв. // Известия Омского государственного историко-краеведческого музея. 1994. № 3. С. 94-114.

Головнев А.В. Коми в северо-западной Сибири // Роль Тобольска в освоении Сибири: Тезисы обл. науч. конф., повященной 400-летию Тобольска (3-5 июня, 1987 г.). Тобольск, 1987. С. 37-38.

Жеребцов И.Л. Коми - жители первых западносибирских городов в конце XVI - первой четверти XVII вв. // Культурное наследие Азиатской России: Материалы I Сибиро-Уральского исторического конгресса (25-27 ноября 1997 г., г. Тобольск). Тобольск, 1997. С. 77-78.

Жеребцов Л.Н. Дороги этнографа. Сыктывкар, 2005. 420 с. (Научное наследие / ИЯЛИ Коми НЦ УрО РАН; Вып. 2).

История Коми: С древнейших времен до конца XX века: В 2 т. Сыктывкар: Коми кн. изд-во, 2004. Т. 1. 558 с.

Конаков Н.Д., Котов О.В. Этноареальные группы коми: Формирование и современное этнокультурное состояние. М.: Наука, 1991. 232 с.

Кириллов А.К., Караваева А.Г., Самульцева Н.Н. Переселенческо-старожильческие конфрликты на заре Великого Сибирского переселения (1870-1880-е гг.): Штрихи к портрету российского общества // Вестник ОмГУ. Сер. Ист. науки. 2017. № 4 (16). С. 44-53.

Кириллов А.К., Гордеева М.А., Караваева А.Г. Сельскохозяйственные ресурсы общего пользования в западносибирской деревне: Механизм возникновения старожильческо-переселенческих конфоликтов в 1870-1890 годы. Антоньевский случай // Историко-экономические исследования. 2017. № 18 (1). C. $193-218$.

Лискевич Н.А., Машарипова А.Х. Формирование и расселение групп коми на территории Ялуторовского уезда Тобольской губернии в XIX - начале XX в. // Вестник археологии, антропологии и этнографии. 2012. № 2. C. 113-119. URL: http://www.ipdn.ru/rics/va.

Повод Н.А. К вопросу о влиянии структуры расселения на этнические процессы мигрантов (на примере коми Западной Сибири) // Академический вестник. 2008. № 1. С. 127-132.

Попов В.Е. Восходовцы. Рукопись. 1982. 114 с.

Справочная книга Тобольской Епархии к 1 сентября 1913 г. Тобольск: Тип. Епархиального братства, 1913. 66 c.

Филатова Н.В. Освоение коми районов Восточного Зауралья // ЭО. 1994. № 5. С. 93-103.

Хоменко Д.Ю. «Различные недоразумения и вражда в резкой форме»: К истории немецких поселений в Енисейской губернии в начале XX в. // Вестник ОмГУ. Сер. Ист. науки. 2018. № 2 (18). С. 110-117.

Худякова М. Переселение коми за Урал: (По материалам переписной книги Яренского уезда 1646 г. и школьной историко-этнографической экспедиции на р. Пелым) // Известия Общества изучения Коми края: Науч.-популяр. краевед. журнал. 2005. № 2 (5). С. 142-146.

\author{
A.Kh. Masharipova \\ Tyumen Scientific Centre of Siberian Branch RAS \\ Malygina st., 86, Tyumen, 625026, Russian Federation \\ E-mail: esenewka@yandex.ru
}

\section{ISSUES ASSOCIATED WITH THE SETTLEMENT OF THE KOMI IN THE YALUTOROVSK DISTRICT OF TOBOLSK GOVERNORATE AND THEIR RELATIONSHIP WITH THE LOCAL POPULATION}

The article discusses the issues associated with the settlement of emigrants from Vologda in a new place in the 19th century drawing on the analysis of archival sources, primarily paperwork materials. An extensive group of sources allowed us to trace and analyse the activities of government bodies, as well as identify the causes of emigration and main problems associated with the settlement in a new place. The analysis of archival materials was supplemented by field studies conducted by the Tyumen Scientific Centre SB RAS in 2005-2008 in the south of the Tyumen Region, where the descendants of the Komi settlers live (Zavodoukovsk, Yurga, Yalutorovsk and Yarkovo Districts). The settlement of Komi family groups from the Vologda Governorate is dated at the first third 


\section{Проблемы обустройства коми переселенцев в Ялуторовском уезде Тобольской губернии...}

of the 19th century and is primarily related to the economic situation of the peasants (shortage of land, poor harvest, growing tax arrears). Most of the immigrants from Vologda settled in the Yalutorovsk District of the Tobolsk Governorate, having established compact settlements in Zavodoukovsk, Ivanovo and Pletnevo volosts. Due to a long period of land management works, the first settlers could not get a job for a long time. With the permission given by the Tobolsk State Chamber in 1841, the Komi-Zyryans settled in the lands of the nonindigenous Tatars (Aslaninskaya Volost), who traditionally used these lands in accordance with the cadastres, annually paying yasak (tribute) to the treasury. The culture, everyday life and the lifestyle of the indigenous population and immigrants differed significantly. Land management works caused great discontent among the indigenous population, which led to numerous land disputes. Difficulties and hardships of immigrants were reflected in the archival documents on the allocation of land and forest allotments, their use, as well as appeals to official authorities (complaints, petitions and legal disputes). When resolving the land dispute, local authorities tried to find a compromise and resolve the conflict through the allotment of vacant state lands. However, the Tatars demanded the return of the land given to the Komi settlers. As a result, the land was allocated to the settlers. As the proper conditions for the settlement were not created, in the following years they had to develop new lands, as well as to establish relations with the surrounding population. Later immigrants were settled on the excess land taken from long-term residents, who did not give it to the settlers and oppressed them. A lot of immigrants due to their plight made a decision to move to other governorates.

Key words: Komi (Zyryans), resettlement, migrant, foreigners, Tartar, Yalutorovsk District of Tobolsk Governorate.

\section{REFERENCES}

Adaev V.N. (2019). Description of extreme Adaptation: Chuvash settlers of the 20th century in deep Siberian Forests. Vestnik arheologii, antropologii i etnografii, (3), 137-148. (Rus.).

Andreev S.M. (2007). Sources of formation of the siberian linear Cossacks during the pre-reforming Period. Izvestiia Tomskogo politekhnicheskogo universiteta, 310(3), 161-165. (Rus.).

Berezhnova M.L. (2009). First Steps in a New Motherland: New Models of Nature Use by Belirussian Immigrants in Urman. Izvestiia AltGU. Ser. Istoriia, 4/3(64), 32-36. (Rus.).

Chuprov V.I. (Ed.) (2004). The history of Komi from ancient times to the end of the twentieth century, 1, Syktyvkar. (Rus.).

Filatova N.V. (1994). Mastering the Komi regions of the Eastern Trans-Urals. Etnograficheskoe obozrenie, (5), 93-103. (Rus.).

Golovnev A.V. (1987). Komi in Northwestern Siberia. In: Rol Tobolska v osvoenii Sibiri: Tezisy obl. nauch. konf., poviashchennoi 400-letiiu Tobol'ska (3-5 iiunia, 1987 g.) (pp. 37-38 ). Tobol'sk. (Rus.).

Khomenko D.IU. (2018). «The Varios Misunderstandings and Hostility in the Sharp Form»: The Story of Migration of Germans to the Yenisei Region in the Early 20th Century. Vestnik Omskogo universiteta, 2(18), 110-117. (Rus.).

Khudiakova M. (2005). Komi resettlement for the Urals. Izvestiia Obshchestva izucheniia Komi kraia: Nauchno-populiarnyi kraevedcheskii zhurnal, 2(5), 142-146. (Rus.).

Konakov N.D., Kotov O.V. (1991). Ethnoareal groups of Komi: Their formation and modern ethic and cultural situation. Moscow: Nauka. (Rus.).

Kirillov A.K., Karavaeva A.G., Samultseva N.N. (2017). Conflicts Between New Settlers and Old Dwellers at the Dawn of the Great Siberian Migration (1870s-1880s): Some Features to the Portrait of the Russian Society. Vestnik Omskogo universiteta, 4(16), 44-53. (Rus.).

Kirillov A.K., Gordeeva M.A., Karavaeva A.G. (2017). Agricultural Common-Pool Resources in the West Siberia Village: Starting Mechanism of Conflicts between Peasant Migrants and Old Dwellers in the 1870s-1890s. The Case of Antonievskaya. Istoriko-ekonomicheskie issledovaniia, 18(1), 193-218.

Liskevich N.A., Masharipova A.Kh. (2012). The formation and resettlement of Komi groups on the territory of the Yalutorovsk district of the Tobolsk province in the 19th - early 20th centuries. Vestnik arheologii, antropologii i etnografii, (2), 113-119. (Rus.).

Povod N.A. (2008). To the question of the influence of the settlement structure on the ethnic processes of migrants (on the example of the Komi of Western Siberia). Akademicheskii vestnik, (1), 127-132. (Rus.).

Vibe P.P. (1994). The resettlement of peasants of European Russia in the Tobolsk province in the second half of the 19th - early 20th centuries. Izvestiia Omskogo gosudarstvennogo istoriko-kraevedcheskogo muzeia, (3), 94-114. (Rus.).

Zherebtsov I.L. (1997). Komi — residents of the first West Siberian cities at the end of the 16th - first quarter of the 17th centuries. In: Materialy I Sibiro-Uralskogo istoricheskogo kongressa (pp. 77-78). Tobol'sk. (Rus.).

Zherebtsov L.N. (2005). Ethnographer's roads. Syktyvkar. (Rus.).

\section{(cc) EY}

This work is licensed under a Creative Commons Attribution 4.0 License.

Submitted: 23.09 .2019

Accepted: 30.09 .2019

Article is published: 30.12 .2019 